\title{
From model to artefact: Versatile characterization of cinnabar, red lead and realgar red paints for rubrics and miniatures
}

\author{
Aušra Čiuladienë \\ Aivaras Kareiva, \\ Rimantas Raudonis \\ Institute of Chemistry, \\ Faculty of Chemistry and Geosciences, \\ Vilnius University, \\ 24 Naugarduko Street, \\ 03225 Vilnius, Lithuania
}

\begin{abstract}
This study focuses on the characterization of cinnabar, red lead and realgar paints, since the red colour was very often used for the illuminations and rubrics of medieval manuscript. The commercial pigments (cinnabar $(\mathrm{HgS})$, red lead $\left(\mathrm{Pb}_{3} \mathrm{O}_{4}\right)$, realgar $\left(\mathrm{As}_{4} \mathrm{~S}_{4}\right)$ ) and binding media (gum Arabic, fish and parchment glue) were used for the preparation of analogous to historical paints. This work is on-going and at this stage, the resulting red paint samples were analysed to create a short data library that could be used to describe the various red paints and their compositions. The obtained paints were characterized before and after accelerated aging using Fourier-transform infrared spectroscopy (FTIR), scanning electron microscopy coupled with energy-dispersive X-ray spectroscopy (SEM/EDX), X-ray diffraction (XRD) and thermal (TG/DSC) analysis techniques. These results of versatile characterization are useful to develop red paint guidelines for the storage and how they affect current and future conservation of these objects.
\end{abstract}

Keywords: cinnabar, red lead, realgar, red paints, binders, accelerated aging, SEM-EDX, XRD, FTIR, TG/DSC analysis

\section{INTRODUCTION}

Various inorganic paints are the most important pigments and the most widespread in our cultural history. The new approach and new research capability provide a unique view of the development of artists' materials, and the different aspects of the research are very useful to enrich one another [1-4]. Investigations of manuscripts related to painting technology and practice are still an active area of research contributing to our understanding of these materials and the history of their use [5-7].

\footnotetext{
* Corresponding author. Email: ausra.ciuladiene@chgf.stud.vu.lt
}

Some pigments show a very high tinting strength and sometimes could be considered as indestructible pigments. However, even for such pigments the negligible degradation could be determined [8-11]. The obtained analytical results provide very important information to the restorers and conservators during their work. These data are also useful for related research on cultural heritage objects.

This study is a continuous work carried out reconstructing red paints using proteinaceous and natural gums binders. Three different red pigments (cinnabar $(\mathrm{HgS})$, red lead $\left(\mathrm{Pb}_{3} \mathrm{O}_{4}\right)$, realgar $\left(\mathrm{As}_{4} \mathrm{~S}_{4}\right)$ ) and their paints will be investigated and discussed in this work. These pigments were used 
very often by miniature artists. In this respect, cinnabar was considered the most prized red pigment. The colour was special because of its deep red, special gloss, good coating properties and adhesive strength. Due to its low hardness and high density, cinnabar was suitable for painting various surfaces. Also, it is very resistant to oxidation or acids, so many very old objects are still showing unchanged bright red colour. The main disadvantage of cinnabar is well known for its transition to black or grey but does not always occur. It depends on the pigment quality and side reactions [8-14]. Red lead was used widely in medieval manuscripts, both alone and with cinnabar. Its toxicity and the possibility of its darkening in some circumstances are regularly cited as disadvantages of the pigment use [5]. Realgar was also used from antiquity until the early 20th century. One of the main features of realgar, widely described in manuscripts, is its sensitivity to light leading to the formation of white arsenic trioxide $\left(\mathrm{As}_{2} \mathrm{O}_{3}\right)[15]$.

Miniature painters, like all other artists, made their own desired shades, mixing two or more colours with the right one proportion. Unfortunately, this practice reduces the ability to identify individual pigments or to determine what might have caused some destruction, using a single test method. In most cases, a mixture of two or more paint creates rather intricate spectra in which the individual substances in the functional group are visible and can be completely hidden other materials [8]. Therefore, non-invasive analytical techniques have not fully satisfied features and cannot be used as a self-consistent analytical tool. The optimal strategy to recognize colourants and other additives used in miniatures or rubrics should, therefore, provide for a multi-technique approach [16].

This study is a continuous work carried out reconstructing red paints using proteinaceous and natural gums binders aimed to clarify how these materials are aging together and create a short data library which could be used for the characterization of red paints in ancient manuscripts. Nine different analogous to ancient red paints using three red pigments (cinnabar, red lead, realgar) and three binding media (gum Arabic, fish glue, parchment glue) were fabricated in this study. The reconstructed paints before and after artificial aging were then characterized by SEM/EDX, FTIR XRD and TG/ DTG/DSC analysis methods.

\section{EXPERIMENTAL}

\section{Materials}

Three different red historical pigments (cinnabar (HgS), (10610), red lead $\left(\mathrm{Pb}_{3} \mathrm{O}_{4}\right),(42500)$ and realgar $\left.\left(\mathrm{As}_{4} \mathrm{~S}_{4}\right),(10800)\right)$, and three binding media (gum Arabic (63320), fish glue (63080) and parchment glue (63035)) were purchased from Kremer Pigmente and used for the preparation of red paints. These samples were characterized at first by XRD, SEM/EDX, FTIR and TG/DTG/DSC analysis. The results of this characterization are already published elsewhere [16].

\section{Paint preparation}

A set of pigment-binding media combinations were prepared in the following way. For the preparation of binding media slightly different procedures were used. The parchment and fish glue were washed with distilled water, cut into small pieces and covered with water for $24 \mathrm{~h}$. Next, the glue was gently heated $\left(40-50^{\circ} \mathrm{C}\right)$ and stirred for $4 \mathrm{~h}$ till became liquid. Then, 9\% acetic acid (Eurochemicals Reachem) solution was added to the prepared binding media with a ratio of 1:4. Gum Arabic was fine-cut, covered with distilled water and was left to swell. Then it was stirred and filtered through linen fabric. Finally, the glue was mixed with the same concentration solution of acetic acid with a ratio of 4:1. The red historical pigments were first ground in an agate mortar with a drop of distilled water and then mixed with the binders resulting in $\sim 85 \mathrm{wt} \%$ of binding media on a dry-paint composition. Nine different analogous to historical red paints were fabricated using the compositions of each red pigment with each binding media. A set of pigment-binding media combination were coated on microscope glass slides and dried in the dark. The prepared samples were artificially aged at intervals of $1,4,7,14,21,28$ and 35 days in a chamber with a constant intensity of UV irradiation of $14887 \mathrm{~mW} / \mathrm{m}^{2}$. Measurements were made using a versatile lux-hygrometer ELSEC 764 UV. The UV source in the aging chamber was a 10-luminescent Osram Eversun L40W/79K fluorescent lamp with a power output of $40 \mathrm{~W}$ ( $400 \mathrm{~W}$ total). Lamps disseminated a wavelength of 310-400 $\mathrm{nm}$ and were hung $50 \mathrm{~cm}$ above the samples. The temperature in the chamber did not exceed $35^{\circ} \mathrm{C}$ and the relative humidity was $21 \% \mathrm{RH}$ [17]. 


\section{Characterization}

The colour change of the paint for all time of accelerated aging was measured with a FLAME-S-VIS-NIRES spectrometer with a light source HL-2000-FHSA $20 \mathrm{~W}$, resolution $\sim 1.5 \mathrm{~nm}$, measuring time $-2 \mathrm{~s}$, measuring range $350-1000 \mathrm{~nm}$, the used standard was WS-1 Reflectance Standard. The surface morphology of the samples and elemental analysis was studied by a scanning electron microscope coupled with energy dispersive X-ray spectroscopy (SEM/EDX) using Hitachi TM3000. IR spectroscopy was used for the identification and characterization of functional groups of pigments and binding media in the paint. Infrared spectra were obtained by an FTIR spectrophotometer Perkin Elmer Spectrum TWO with ATR accessory. All spectra were recorded at $4 \mathrm{~cm}^{-1}$ resolution in an interval of $450-4000 \mathrm{~cm}^{-1}$ and 24 scans were accumulated before Fourier transformation. $\mathrm{X}$-ray diffraction (XRD) analysis was performed using Benchtop XRD MiniFlex II, Rigaku in a range of 10 to $80^{\circ} 2 \theta, 5^{\circ} / \mathrm{min}$. speed, using $\mathrm{CuK}_{\alpha 1}$ radiation. Thermal analysis (TG/DTG/DSC) was recorded using a Perkin Elmer pyris TGA instrument. The heating rate was $10^{\circ} \mathrm{C} / \mathrm{min}$ in air flow from 30 to $900^{\circ} \mathrm{C}$.

\section{RESULTS AND DISCUSSION}

\section{Colorimetric measurements}

Visual examination of the paint samples showed that some of the paint had a noticeable colour changed after accelerated aging (see Fig. 1). Each sample was photographed under the same lighting and at the same height from the sample to capture the appropriate colour. Since the binding media are transparent their photos were made using a white sheet of the paper base.

The colour measurements of all non-aged and aged samples were performed. The colour difference $\Delta \mathrm{E}$ in the $\mathrm{CIE}(\mathrm{Lab})^{*}$ system of paints was calculated according to Eq. (1) [17-19]:

$$
\Delta \mathrm{E}=\left[\left(\Delta \mathrm{L}^{*}\right)^{2}+\left(\Delta \mathrm{a}^{*}\right)^{2}+\left(\Delta \mathrm{b}^{*}\right)^{2}\right]^{1 / 2} .
$$

Here $\Delta \mathrm{L}^{*}$ (lightness-darkness difference $)=\mathrm{L}_{\text {aged }}{ }$ $\mathrm{L}^{*}$ non-aged, $\Delta \mathrm{a}^{\star}($ redness-greenness difference $)=$ $\mathrm{a}^{*}{ }_{\text {aged }}-\mathrm{a}^{*}{ }_{\text {non-aged }}$ and $\Delta \mathrm{b}^{*}$ (yellowness-blueness difference $)=\mathrm{b}^{*}{ }_{\text {aged }}-\mathrm{b}^{*}{ }_{\text {non-aged }}$

The colour changes and colour difference of red paints and binding media before and after accelerated aging are represented in Fig. 1 and Table 1.

From the digital images, as we can see, the smallest deep red colour change was observed in cinnabar. The colour difference is $\leq 3$, except for the cinnabar with the fish glue $\Delta \mathrm{E}$ value is 6.9 and the paint looks a bit brighter. It is important to note that the $\Delta \mathrm{E} \geq 3$ colour difference is observed in human eyes [20]. Red lead pigment produced the paint with redorange colour. A visual assessment of the colour of the pigment with different binders shows that the colours are very close with gum Arabic and parchment glue, except, the paint with gum Arabic

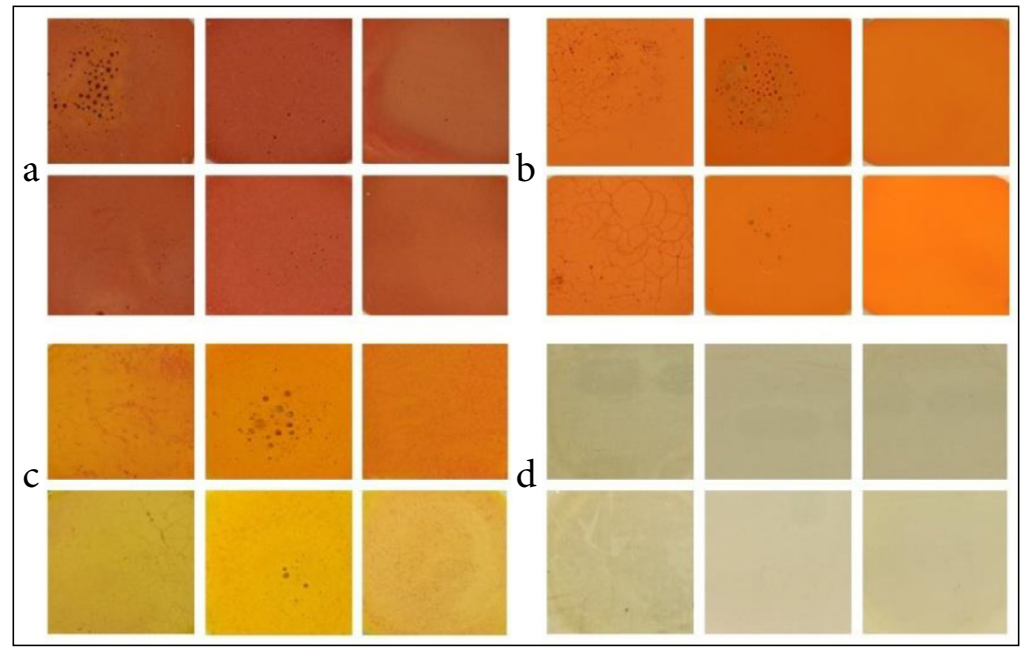

Fig. 1. The digital images of paints fabricated from mixtures of cinnabar (a), red lead (b) and realgar (c) with gum Arabic, fish glue and parchment glue, and binding medias (d) gum Arabic, fish glue and parchment glue (from left to right) before (top) and after 35 days accelerated aging (bottom) (coloured online) 
Table 1. Determined $\Delta E$ values for the fabricated red paints after 35 days aging

\begin{tabular}{|c|c|c|c|c|c|c|c|}
\hline \multirow{2}{*}{$\begin{array}{l}\text { Pigment } \\
\text { Before }\end{array}$} & & \multicolumn{2}{|c|}{ Gum Arabic } & \multicolumn{2}{|c|}{ Fish glue } & \multicolumn{2}{|c|}{ Parchment glue } \\
\hline & & Before & After & Before & After & Before & After \\
\hline \multirow{4}{*}{ Cinnabar } & $\mathrm{L}^{*}$ & 52.6 & 50.7 & 56.1 & 53.2 & 65.9 & 65.1 \\
\hline & $a^{*}$ & 37.8 & 36.2 & 42.2 & 38.5 & 39.8 & 38.7 \\
\hline & $b^{*}$ & 31.5 & 30.5 & 32.8 & 27.7 & 32.9 & 31.5 \\
\hline & $\Delta \mathrm{E}$ & - & 2.7 & - & 6.9 & - & 2.0 \\
\hline \multirow{4}{*}{ Red lead } & $L^{*}$ & 70.9 & 69.3 & 67.8 & 65.6 & 78.1 & 72.9 \\
\hline & $a^{*}$ & 51.1 & 48.8 & 50.5 & 47.3 & 52.4 & 49.3 \\
\hline & $b^{*}$ & 54.3 & 56,7 & 54.9 & 57.6 & 61.1 & 56.5 \\
\hline & $\Delta \mathrm{E}$ & - & 3.7 & - & 4.7 & - & 7.7 \\
\hline \multirow{4}{*}{ Realgar } & $\mathrm{L}^{*}$ & 74.6 & 75.4 & 72.9 & 73.5 & 75.5 & 83.7 \\
\hline & $a^{*}$ & 42.9 & 16.1 & 40.7 & 20.9 & 43.6 & 15.9 \\
\hline & $b^{*}$ & 57.8 & 43.3 & 62.8 & 59.7 & 55.4 & 25.5 \\
\hline & $\Delta \mathrm{E}$ & - & 30.4 & - & 20.0 & - & 41.5 \\
\hline
\end{tabular}

before aging was cracked. The more intensive colour before aging was of the paint obtained from red lead with fish glue. After accelerated aging, the colour changed considerably. The colour difference $\Delta \mathrm{E}$ was 3.7 with gum Arabic, 4.7 with fish glue and 7.7 with parchment glue. The paint with gum Arabic was cracked after accelerated aging also showing a low adhesion of the paint to the surface. The same effect (lower adhesion and pigment 'dusting') was observed with the remaining binders. The colour of red lead with parchment glue has changed from redorange to orange after accelerated aging. The biggest colour change determined from the digital images of paints was observed for realgar pigment based paints. The colour with different binders before aging was bright red-orange, and the paint did not crack. After accelerated aging the paint with gum Arabic was cracked, and the colour faded to a greenish tint with a colour difference of 30.4. The paint with fish glue changed the colour to brightly yellow. There was the pigment 'dusting' process, and the $\Delta \mathrm{E}$ was 20.0. The biggest colour change to beige was observed for the paint with parchment glue, and $\Delta \mathrm{E}$ was 41.5 . The paint also had a poor adhesion to the surface.

\section{SEM/EDX analysis}

SEM analysis was performed to evaluate the morphologic changes of the paint before and after accelerated aging. The SEM micrographs for different paints are presented in Fig. 2.

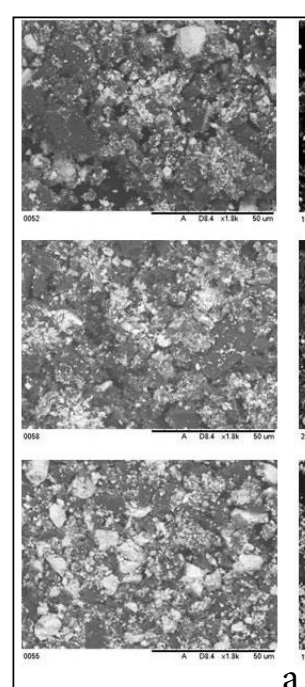

a
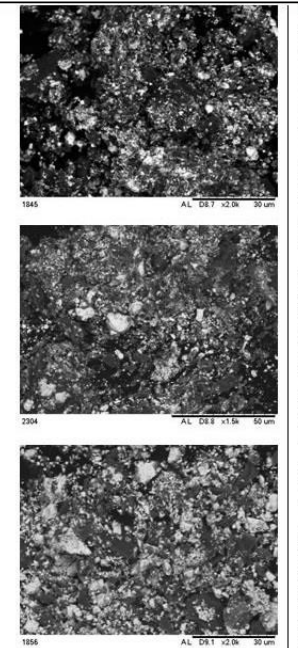

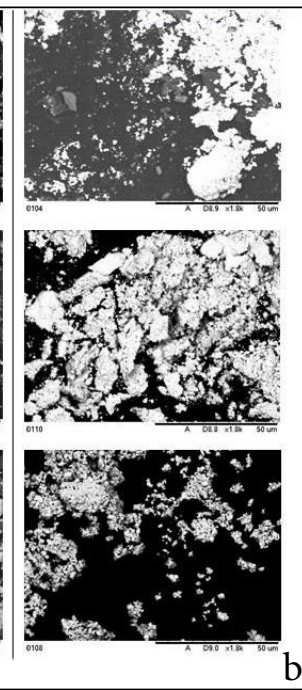

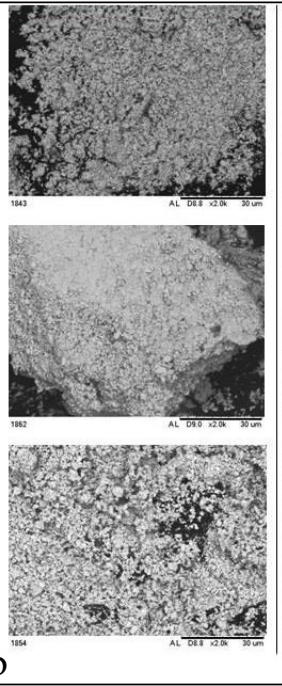

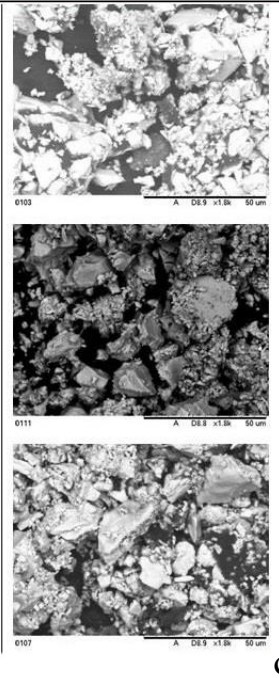

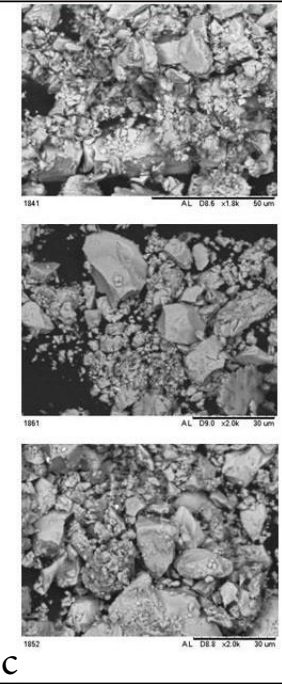

Fig. 2. SEM micrographs of different paint composition of cinnabar (a), red lead (b) and realgar (c) with (from top to bottom) gum Arabic, fish and parchment glue before (left) and after 35 days of accelerated aging (right) 
The surface morphology of cinnabar paints is very similar independent of the binding media used. The surface is mostly composed of plate-like particles (see Fig. 2a). The particle size of paint with gum Arabic and fish glue was not affected by accelerated aging (1-15 $\mu \mathrm{m}$ before and $1-10 \mu \mathrm{m}$ after aging with gum Arabic and 1-5 $\mu \mathrm{m}$ before and after aging with fish glue). The biggest changes in particle size were determined for the paint of cinnabar with parchment glue. The particle size varied from 1 to $15 \mu \mathrm{m}$ before aging and from 1 to $3 \mu \mathrm{m}$ after artificial aging. The biggest changes of surface morphology before and after artificial aging were observed for the paints fabricated with red lead pigment (Fig. 2b). The paints were composed of differently shaped particles with a size of 1-10 $\mu \mathrm{m}$ before aging. However, the particle size decreased significantly after accelerated aging. Moreover, these mostly spherically shaped particles showed a tendency to form hard agglomerates.

The morphological features determined for the realgar paints were almost identical as for the case of cinnabar (see Fig. 2c). Volumetric rectangular particles of 5-40 $\mu \mathrm{m}$ in size have formed and no specific changes after aging were observed.

\section{FTIR spectroscopy}

FTIR spectroscopy has been used to better understand the colour change of paint during accelerated aging, providing additional information. FTIR spectra of binding media before and after accelerated aging did not change, so these results confirm that artificial aging does not destroy the chemical composition of gum Arabic, fish glue and parchment glue. The main vibrations could be attributable to the functional groups of binding media and acetic acid [21-23]. The representative absorption bands observed in the FTIR spectra of red paints with various compositions are listed in Table 2.

The absorption bands specific to gum Arabic are observed at $3200-3400 \mathrm{~cm}^{-1}$ attributable to the stretch vibrations of $\mathrm{OH}$ group, the bands visible at $2910-2925 \mathrm{~cm}^{-1}$ are due to $\mathrm{C}-\mathrm{H}$ stretch and indicate the presence of sugars, galactose, arabinose and rhamnose. The FTIR spectra of gum Arabic also showed the characteristic bands of $\mathrm{C}=\mathrm{C}$ stretch, amide $\mathrm{NH}$ bend, $\mathrm{NO}_{2}$ from both aliphatic and aromatic galacto proteins, and amino acids around $1600 \mathrm{~cm}^{-1}$. Glucuronic acids have a specific vibrations band at about 1410 and $1360 \mathrm{~cm}^{-1}$ due to $\mathrm{C}=\mathrm{O}$ symmetric stretching and $\mathrm{OH}$ bending, respective- ly. A distinct band at around $1030 \mathrm{~cm}^{-1}$ represents alkene $\mathrm{C}-\mathrm{H}$ band from polysaccharides for all gum samples [24, 25].

The FTIR spectra of fish glue and parchment glue are almost identical since collagen is the main component of these materials. The assignment of absorption bands visible at 3200 and $3400 \mathrm{~cm}^{-1}$ is the same as for gum Arabic. A typical absorption band in a region of $3400-3500 \mathrm{~cm}^{-1}$ for the amino group is masked by a broad absorption band of the $\mathrm{OH}$ group [25]. Absorption bands of amides coupled to $\mathrm{C}=\mathrm{O}$ are at about $1630 \mathrm{~cm}^{-1}$ (amide I), at $1530 \mathrm{~cm}^{-1}$ (amide II) and at $1230 \mathrm{~cm}^{-1}$ (amide III) [26.

It is known that the red pigment cinnabar does not absorb infrared radiation in a range of 4000$350 \mathrm{~cm}^{-1}$; however, an intensive absorption band at $1100-1000 \mathrm{~cm}^{-1}$ presented in Table 2 corresponds to our investigated red paint cinnabar fabricated with different binding media. This band could be attributed to the characteristic vibration of $\mathrm{Si}-\mathrm{O}$ bond confirming the presence of silica impurity in commercial cinnabar pigment. The absorption peaks determined at $780-720$ and $695-690 \mathrm{~cm}^{-1}$ could be attributed to the $\mathrm{Si}-\mathrm{O}-\mathrm{Al}$ vibrations. Red lead has infrared absorption bands in low frequency regions of $680-531 \mathrm{~cm}^{-1}$ and one band at $1398-1390 \mathrm{~cm}^{-1}$ which is characteristic of lead oxide [23]. New peaks in the red lead paint with different binders are not seen after accelerated aging, only one small peak at $510 \mathrm{~cm}^{-1}$ with gum Arabic, which could be assigned to the binder. Before accelerated aging, no bands other than binding media were detected in the FTIR spectra of realgar paint. After accelerated aging, the realgar paint with gum Arabic showed a new peak at $1722 \mathrm{~cm}^{-1}$. It could be attributed to the vibration of the double bond in $\mathrm{C}=\mathrm{O}$ from binding media. Three new peaks were noticed in the paint with fish and parchment glue at 1040, 800 and $478 \mathrm{~cm}^{-1}$. The first peak is attributed to a $\mathrm{C}-\mathrm{O}$ carboxyl group in both binding media and the second group to a specific As-O vibration band, which could be linked to the paint discolouration. Arsenic trioxide and various sulphate compounds are expected to be formed as degradation products for all the arsenic sulphide pigments. Aging of arsenic sulphide containing painting systems often leads to whitening or increased transparency due to the formation of water-soluble white arsenic trioxide and/or arsenate species plane movements [27]. The origin of the main band detected at $478 \mathrm{~cm}^{-1}$ is related with the As-S vibration [28, 29]. 
Table 2. List of red pigments absorption bands before and after accelerated aging

\begin{tabular}{|c|c|c|c|}
\hline $\begin{array}{l}\text { Binding } \\
\text { media }\end{array}$ & \multicolumn{2}{|c|}{ Pigment } & IR bands, $\mathrm{cm}^{-1}$ \\
\hline \multirow{6}{*}{$\begin{array}{l}\frac{u}{0} \\
\frac{0}{0} \\
\frac{\pi}{5} \\
\frac{5}{0}\end{array}$} & \multirow{2}{*}{ Cinnabar } & Before & 3348 m, 2920 w, 1620 w, 1420 w, 1001 s, 780 s, 692 w \\
\hline & & After & 3348 m, 1620 w, 1420 w, 1001 s, 780 w, 582 n, 530 n \\
\hline & \multirow{2}{*}{ Red lead } & Before & 3290 w, 2913 w, 1551 m, 1398 m, 1048 m, 665 w \\
\hline & & After & 1551 w, 1398 w, 1048 m, 665 w, 510 n \\
\hline & \multirow{2}{*}{ Realgar } & Before & 3300 m, 2913 w, 1597 m, 1012 m \\
\hline & & After & 3300 s, 2913 m, 1722 n, 1597 m, 1012 s \\
\hline \multirow{6}{*}{$\begin{array}{l}\frac{0}{\sigma} \\
\frac{c}{n} \\
\frac{n}{4}\end{array}$} & \multirow{2}{*}{ Cinnabar } & Before & 3348 w, 1634 m, 1530 m, 1430 w, 1007 s, 775 s, 692 m, 645 m, 582 m \\
\hline & & After & 3348 w, 1634 m, 1530 w, 1430 w, 1007 s, 775 m,692 w, 645 w, 582 w \\
\hline & \multirow{2}{*}{ Red lead } & Before & 3300 w, 2920 w, 1634 m, 1529 m, 1395 m, 665 m \\
\hline & & After & 3300 w, 1634 m, 1529 m, 1396 m, 665 w \\
\hline & \multirow{2}{*}{ Realgar } & Before & 3305 w, 2915 w, 1629 m, 1530 m, 1229 w \\
\hline & & After & 1629 m, 1530 m, 1040 n, 800 n, 478 n \\
\hline \multirow{6}{*}{ 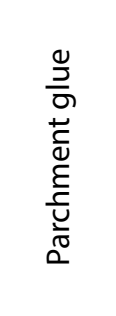 } & \multirow{2}{*}{ Cinnabar } & Before & 3286 w, 1639 m, 1535 w, 1442 w, 1001 s, 774 s, 691 m, 582 w \\
\hline & & After & 1639 w, 1535 w, 1442 w, 1001 s, 774 s, 691 w, 582 w \\
\hline & \multirow{2}{*}{ Red lead } & Before & $1630 \mathrm{~m}, 1530 \mathrm{~m}, 1395 \mathrm{~m}, 680 \mathrm{~m}$ \\
\hline & & After & $1630 \mathrm{~m}, 1530 \mathrm{~m}, 1395 \mathrm{~m}, 680 \mathrm{w}$ \\
\hline & \multirow{2}{*}{ Realgar } & Before & $1630 \mathrm{w}, 1524 \mathrm{w}, 1235 \mathrm{w}$ \\
\hline & & After & $1630 w, 1524$ w, 1235 w, 1038 n, 800 n, 475 n \\
\hline
\end{tabular}

s, sharp peaks; m, medium bands; w, weak bands; $n$, new bands.

\section{XRD analysis}

The XRD analysis of fabricated red paints before and after aging was also performed. The XRD patterns of six investigated red paints (obtained with cinnabar and red lead) were almost identical before and after aging. The XRD patterns of cinnabar with different binders showed the diffraction peaks attributable to the main $\mathrm{HgS}$ crystalline phase (PDF 00-075-1589). Also, the XRD patterns contain an additional $\mathrm{SiO}_{2}$ phase (PDF 00-078-1253) at $2 \theta=26.60,36.37,37.68,45.68$ and $59.84^{\circ}$. According to the XRD analysis data, the paint of red lead with gum Arabic consists only of $\mathrm{Pb}_{3} \mathrm{O}_{4}$ (PDF 00-041-1493). However, in the XRD patterns of red lead with fish glue and parchment glue diffraction lines at $2 \theta=17.69^{\circ}$ and at $2 \theta=50$ to $60^{\circ}$ were determined showing the possible formation of $\mathrm{PbO}$ after aging. The binding media used for the preparation of red paints are amorphous materials, but it is known that for pure gum Arabic the diffraction line located at $2 \theta=18.9^{\circ}$ in the XRD pattern is attributable for collagen. The collagen is also the main component in fish and parchment glue [30-32]. However, only the characteristic diffractions of collagen were observed only in the XRD patterns of cinnabar and red lead paints with fish glue. The characteristic peaks of other binders were no detected in the XRD patterns of these paints.

The XRD patterns of red paints with realgar were quite different before and after artificial aging (see Fig. 3). Realgar, which is red mineral, $\mathrm{As}_{4} \mathrm{~S}_{4}$, partially transforms in arsenolite (white powder, $\mathrm{As}_{2} \mathrm{O}_{3}$ ) and pararealgar (yellow, $\mathrm{As}_{4} \mathrm{~S}_{4}$ ) and the $\chi$-phase $\left(\mathrm{As}_{4} \mathrm{~S}_{5}\right)$ when is exposed to light.

Pararealgar has the same formula as realgar, and is characterized having a different structural arrangement of sulphur and arsenic atoms. At the end of the process, $\mathrm{As}_{4} \mathrm{~S}_{5}$ co-exists with pararealgar, and the colour of pigment turns from red-orange to yellow [33]. In the XRD pattern of realgar paints, after aging the diffractions attributed to arsenolite and pararealgar were detected. The XRD patterns of realgar paints with gum Arabic and with fish glue have diffraction lines at $2 \theta=8.99$ and $12.85^{\circ}$ from pararealgar, and $2 \theta=13.62$ and $25.13^{\circ}$ from arsenolite. The XRD patterns of realgar paint with parchment glue have also diffractions attributable to the pararealgar phase. 


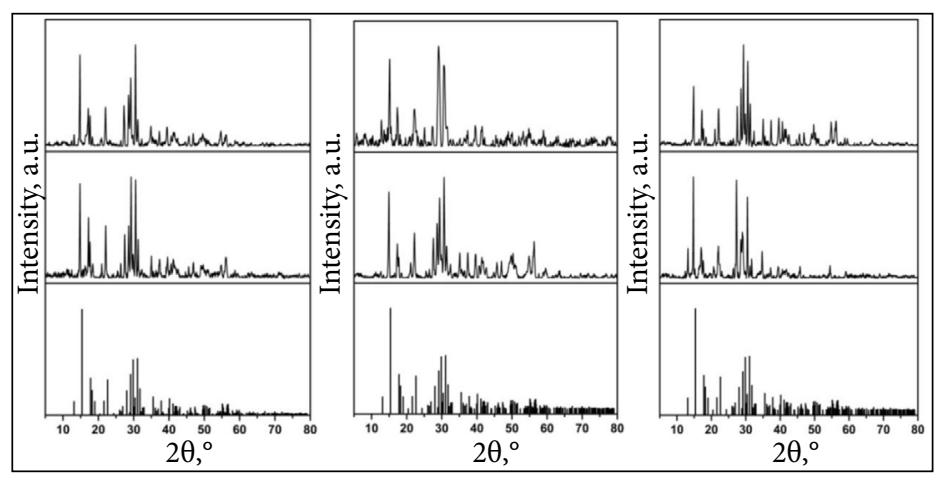

Fig. 3. XRD patterns of realgar paint with gum Arabic (left), fish glue (middle) and parchment glue (right) before (middle) and after accelerated aging (top) for 35 days. The standard XRD pattern of $\mathrm{As}_{4} \mathrm{~S}_{4}$ is presented as vertical lines at the bottom

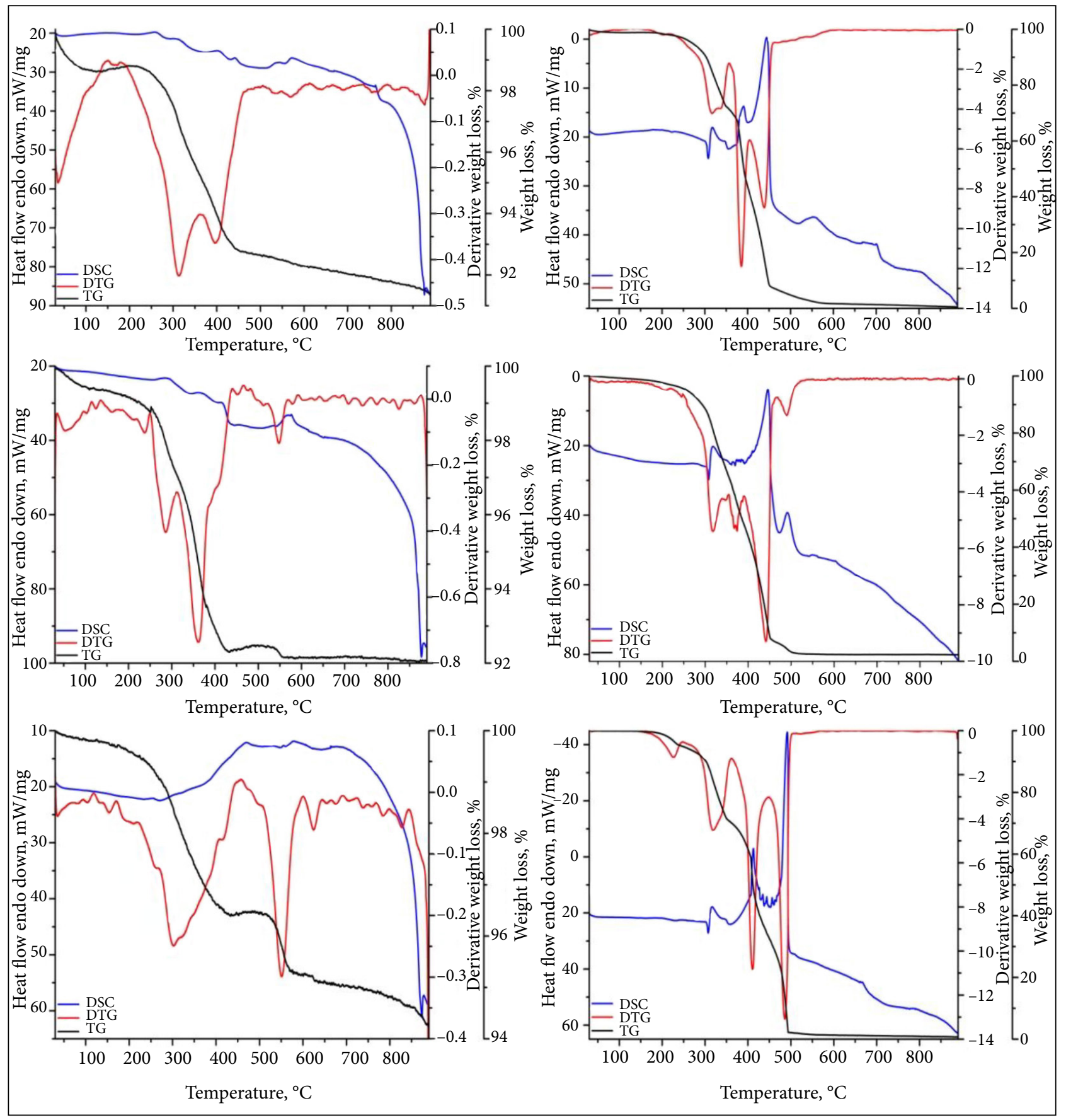

Fig. 4. TG/DTG/DSC curves of red lead (left) and realgar (right) with fish glue (top), gum Arabic (middle) and parchment glue (bottom) after 35 days aging (coloured online) 


\section{TG analysis}

The TG/DTG/DSC curves of cinnabar paints in all composition are very similar. The first mass loss $(\sim 5$ and $\sim 2 \%$ before and after aging, respectively) observed in a temperature range of $30-230^{\circ} \mathrm{C}$ is due to the loss of adsorbed and structural water of gums. The second mass loss of about $30 \%$ before and $37 \%$ after aging observed at $260-410^{\circ} \mathrm{C}$ is related to the decomposition of polysaccharide. The structural changes of cinnabar in a temperature range of $300-410^{\circ} \mathrm{C}$ could also occur. The hexagonal red mercury sulphide $\alpha-\mathrm{HgS}$ rearranges to the black mercury sulphide $\beta$-HgS having a cubic crystal structure in this temperature interval. The formation of metacinnabar mixed with other black amorphous product is also possible [6, 34]. The final mass loss in a temperature range of $400-600^{\circ} \mathrm{C}$ is associated with the thermal decomposition of intermediate residues formed in carboxymethylated samples. Figure 4 shows the TG/DTG/DSC curves of red lead and realgar paints synthesized with the gum Arabic, fish and parchment glue.

The main weight losses could be explained in the same manner as in the case of cinnabar paint. However, for the red lead paints a negligible weight gain is seen in a temperature range of $450-550^{\circ} \mathrm{C}$. This is related with the reversible oxidation-reduction process (2) [35]:

$$
2 \mathrm{~Pb}_{3} \mathrm{O}_{4} \leftrightarrow 6 \mathrm{PbO}+\mathrm{O}_{2}
$$

The realgar at about $250^{\circ} \mathrm{C}$ temperature, under normal pressure, transforms to the pararealgar $\left(\mathrm{As}_{4} \mathrm{~S}_{4}\right)$ phase, which was detected in the paints after aging by XRD analysis. Pararealgar melts at about $310^{\circ} \mathrm{C}$ temperature, which is supported by endotherms visible in the DSC curves. Next, in a range of about $350-430^{\circ} \mathrm{C}$ the transformation of pararealgar to arsenolite takes place. And finally, the material formed starts to evaporate in a temperature range of $430-500^{\circ} \mathrm{C}$ as exothermic process [36].

\section{CONCLUSIONS}

In this work, nine different red paint compositions and their changes during accelerated aging have been studied. Cinnabar $(\mathrm{HgS})$, red lead $\left(\mathrm{Pb}_{3} \mathrm{O}_{4}\right)$ and realgar $\left(\mathrm{As}_{4} \mathrm{~S}_{4}\right)$ red pigments were combined with binding media (gum Arabic, fish glue and parchment glue) to obtain red paints. Visually, the fabricated paints with cinnabar exhibited deep red colour, and the colour of paints with red lead and realgar was red-orange. After accelerated aging, the biggest colour change was observed for the realgar paints. These red paints have brightened and turned to yellowish colour. The red lead paints changed the colour negligibly, and the paints fabricated with cinnabar sustained colour almost without any changes. According to the SEM micrographs, the surface morphology of red paints has not changed significantly after 35 days of artificial aging. However, the particle size in most of the cases decreased significantly after accelerated aging. Moreover, the tendency to form hard agglomerates was also observed. On the other hand, the FTIR spectroscopy results let us to conclude that the artificial aging had some deleterious effect on the fabricated red paints with realgar. There was a new absorption band attribute able to the specific AsO vibration and some additional bands originating from binging media in the FTIR spectra of paints. The XRD analysis results confirmed the FTIR spectroscopy data. The XRD patterns of cinnabar with different binders before and after artificial aging showed the diffraction peaks attributable to the main HgS crystalline phase. However, in the XRD patterns of red lead with fish glue and parchment glue after aging, the diffraction lines attributable to the $\mathrm{PbO}$ were determined. The XRD patterns of red paints with realgar showed the formation of transforms in arsenolite, pararealgar and $\mathrm{As}_{4} \mathrm{~S}_{5}$ during the artificial aging. The thermal analysis of red paints before and after accelerated aging showed that the most thermal events observed in the TG/DTG/DSC curves were related with the changes of the chemical composition of binding media and with the phase transformations of realgar.

Received 14 September 2020 Accepted 21 September 2020

\section{References}

1. L. Giorgi, A. Nevin, D. Comelli, et al., Spectrochim. Acta A Molec. Biomolec. Spectrosc., 219, 504 (2019).

2. B. Serment, L. Corucho, A. Demourgues, et al., Inorg. Chem., 58, 7499 (2019).

3. A. Kareiva, A. Beganskiene, J. Senvaitiene, et al., Coll. Surf. A Physicochem. Eng. Aspects, 580, 123718 (2019). 
4. F. Pozzi, E. Basso, A. Rizzo, et al., J. Raman Spectrosc., 50, 861 (2019).

5. R. L. Feller, Artists' Pigments: A Handbook of Their History and Characteristics, Vol. 1, National Gallery of Art, Washington (1986).

6. A. Roy, Artists' Pigments: A Handbook of Their History and Characteristics, Vol. 2, National Gallery of Art, Washington (1993).

7. E. W. FitzHugh, Artists' Pigments: A Handbook of Their History and Characteristics, Vol. 3, National Gallery of Art, Washington (1997).

8. J. Senvaitiene, I. Pakutinskiene, A. Beganskiene, et al., Polish J. Chem., 79, 1575 (2005).

9. G. C. Gargori, L. S. Cerro, N. F. Argamasilla, et al., Boletín Socied. Es. Cerám. Vidrio, 56, 166 (2017).

10. R. Dang, Y. Yuan, G. Liu, et al., Color Res. Appl., 43, 596 (2018).

11. M. M. Urbanczyk, K. Bester, N. Borho, et al., J. Hazard. Mater., 364, 125 (2019).

12. M. Aceto, A. Agostino, G. Fenoglio, et al., Anal. Methods, 6, 1488 (2014).

13. R. Nöller, Stud. Conserv., 60, 79 (2015).

14. M. J. Melo, R. Araújo, R. Castro, et al., Microchem. J., 124, 837 (2016).

15. M. Vermeulen, K. Janssens, J. Sanyova, et al., Microchem. J., 138, 82 (2018).

16. A. Čiuladienè, A. Luckutè, J. Kiuberis, et al., Chemija, 29, 243 (2018).

17. D. Ragauskienè, R. Makuška, Chemija, 17, 52 (2006).

18. N. Baer, R. L. Feller, J. Americ. Inst. Conserv., 35, 163 (1996).

19. O. Opuchovič, G. Kreiza, J. Senvaitienè, et al., Dyes Pigm., 118, 176 (2015).

20. K. Elert, A. Herrera, C. Cardell, Dyes Pigm., 148, 236 (2018).

21. S. Kroustallis, Revista de História da Arten. Serie W, 1, 105 (2011).

22. D. M. Goltz, Anal. Let., 45, 314 (2012).

23. A. Vila, J. F. García, Anal. Let., 45, 1274 (2012).

24. Y. Don, K. M. Sørensen, S. He, et al., Food Contr., 78, 144 (2017).

25. R. M. A. Daoub, A. H. Elmubarak, M. Misran, et al., J. Saud. Soc. Agricult. Sci., 17, 241 (2018).

26. B. De Campos Vidal, M. L. S. Mello, Micron., 42, 283 (2011).

27. M. Vermeulen, K. Janssens, J. Vanoushe Rahemi, et al., Microchem. J., 138, 82 (2018).

28. M. Manfredi, G. Bearman, F. France, et al., J. Conserv. Sci., 6, 3 (2015).
29. A. Lashgari, S. Ghamami, Z. Bahrami. J. Nanomat., Art. ID 130698, 1 (2015).

30. F. Niu, M. Kou, J. Fan, et al., Food Chem., 260, 1 (2018).

31. N. Davidenko, J. J. Campbell, E. S. Thian, et al., Acta Biomater., 6, 3957 (2010).

32. K. Wang, W. Wang, R. Ye, et al., Food Chem., 216, 209 (2017).

33. A. Macchia, L. Campanella, D. Gazzoli, et al., Proc. Chem., 8, 185 (2013).

34. C. Miguel, J. V. Pinto, M. Clarke, et al., Dyes Pigm., 102, 210 (2014).

35. J. P. McKinley, M. K. Dlaska, R. Batson. J. Pow. Sourc., 107, 180 (2002).

36. M. Zoppi, G. Pratesi. Americ. Miner., 97, 890, (2012).

Aušra Čiuladienè, Aivaras Kareiva, Rimantas Raudonis

NUO MODELIO IKI ARTEFAKTO:

UNIVERSALUS CINOBERIO, RAUDONOJO

ŠVINO IR REALGARO RAUDONŲ DAŽŲ,

NAUDOJAMŲ RUBRIKOMS IR MINIATIÜROMS,

\section{APIBŪDINIMAS}

Santrauka

Darbe pagrindinis demesys yra skiriamas cinoberio, raudonojo švino ir realgaro dažams apibūdinti, nes jie ypač dažnai buvo naudojami rankraščių puošybai, rubrikoms ir miniatiūroms. Analogiškiems istoriniams dažams gaminti buvo naudojami komerciniai pigmentai (cinoberis $(\mathrm{HgS})$, raudonasis švinas $\left(\mathrm{Pb}_{3} \mathrm{O}_{4}\right)$, realgaras $\left(\mathrm{As}_{4} \mathrm{~S}_{4}\right)$ ) ir rišamosios medžiagos (gumiarabikas, žuvų ir pergamento klijai), ịsigyti iš Kremer Pigmente. Paruošti dažai buvo dirbtinai sendinti fotocheminèje sendinimo kameroje ir tam tikrais intervalais tirti Furjè infraraudonosios spektroskopijos (FTIR), skenuojančios elektroninès mikroskopijos su rentgeno spinduliu energijos dispersine spektrometrija (SEM/EDX), rentgeno spindulių difrakcinès (XRD) analizès ir terminės (TG/DTG/DSC) analizès metodais. Gauti duomenys parode, kad didžiausi pokyčiai vyksta raudonojo švino ir realgaro dažuose: intensyviausiai keitesi spalva, dalelių dydis, formavosi šalutiniai produktai. Šis darbas yra tęstinis, gauti duomenys leis papildyti turimą raudonų dažų duomenų bazę. Ja bus galima naudotis apibūdinant ivvairias dažų kompozicijas, turima informacija prisidès išsaugant ir restauruojant realius objektus. 